\title{
Utilization of nitrogen in cows consuming wet distillers grains with solubles in alfalfa and corn silage-based dairy rations
}

\author{
A. M. Gehman and P. J. Kononoff ${ }^{1}$ \\ Department of Animal Science, University of Nebraska, Lincoln 68583-0908
}

\begin{abstract}
The objectives of this experiment were to determine the effects of forage type on nutrient digestibility, purine derivative excretion, nitrogen utilization, and milk production in dairy cattle consuming rations containing high levels of wet distillers grains with solubles (WDGS). Primiparous $(\mathrm{n}=8)$ and multiparous $(\mathrm{n}=$ 20) Holstein cows were used in a replicated $4 \times 4$ Latin square. Animals were fed 1 of 4 treatments during each 21-d period: 1) CONT-CS, 0\% WDGS and high corn silage; 2) CONT-AS, 0\% WDGS and high alfalfa silage; 3) WDGS-CS, $25 \%$ WDGS and high corn silage; and 4) WDGS-AS, 25\% WDGS and high alfalfa silage (dry matter basis). Intake and milk data were collected daily and averaged for d 15 to 21 of each period. Dry matter intake was lower for CONT-CS than for CONT-AS, WDGS-CS, and WDGS-AS (22.5, 24.6, 24.6, and 24.8 $\mathrm{kg} / \mathrm{d}$, respectively). Digestibility of dry matter, organic matter, neutral detergent fiber, and $\mathrm{N}$ were not affected by treatment, averaging 59.6, 62.3, 40.1, and 58.6\%, respectively. Excretion of urinary purine derivatives was greatest for WDGS-AS, followed by WDGS-CS, and then CONT-CS and CONT-AS. Thus, by calculation, estimated microbial protein flow was highest for WDGS-AS $(2,189.9 \mathrm{~g} / \mathrm{d})$ followed by WDGS-CS $(1,996.2 \mathrm{~g} / \mathrm{d})$, CONT-AS $(1,640.0 \mathrm{~g} / \mathrm{d})$, and CONT-CS $(1,627.0 \mathrm{~g} / \mathrm{d})$. Mass of fecal $\mathrm{N}$ was not different among treatments (averaging $287.1 \pm 14.8 \mathrm{~g} / \mathrm{d}$ ), but urinary and manure $\mathrm{N}$ were reduced for rations with WDGS compared with those not including WDGS. Observed $4 \%$ fat-corrected milk was greatest for WDGS-AS, followed by WDGS-CS, and then CONT-CS and CONTAS $(30.7,29.7,28.3$, and $27.2 \mathrm{~kg} / \mathrm{d}$, respectively). Milk protein yield was greatest for WDGS-AS (1.00 $\mathrm{kg} / \mathrm{d}$ ), followed by WDGS-CS, and then CONT-AS and CONT-CS $(0.96,0.91,0.86 \mathrm{~kg} / \mathrm{d}$, respectively). This research demonstrated that rations can be balanced for dairy cattle to include up to $25 \%$ WDGS and result in
\end{abstract}

Received December 1, 2009.

Accepted March 1, 2010.

${ }^{1}$ Corresponding author: pkononoff2@unl.edu increased microbial protein synthesis, milk production, and milk protein yield.

Key words: wet distillers grains with solubles, forage, dairy, nitrogen

\section{INTRODUCTION}

Wet distillers grains with solubles (WDGS) are coproducts of the dry corn milling industry. This feedstuff may serve as a valuable source of energy and protein for lactating dairy cows. Given that a large proportion of starch is utilized during the ethanol production process, the energy in WDGS is largely found in fiber and fat components of the feedstuff. A large proportion of the protein found in WDGS is classified as zein, much of which bypasses rumen fermentation (Klopfenstein et al., 2008). When replacing high-energy feedstuffs that are lower in CP, such as corn grain and silage, WDGS may increase CP content of rations (Schingoethe et al., 1999) and, as a result, the amount of total $\mathrm{N}$ consumed. This is a concern because increased $\mathrm{N}$ intake is directly related to increased $\mathrm{N}$ excretion in feces and urine by the animal (Broderick, 2003; Groff and Wu, 2005). Nitrogen losses from manure represent one of the greatest environmental impacts of dairy production (VandeHaar and St-Pierre, 2006).

The source of forage in rations that contain high levels of WDGS may influence ruminal fermentation and nutrient digestibility, and ultimately $\mathrm{N}$ excretion. Kleinschmit et al. (2007) observed that when alfalfa hay replaced corn silage (CS) in a ration containing 15\% dried distillers grains with solubles (DDGS), AA extraction by the mammary gland and milk protein secretion was improved, indicating an effect of forage type on $\mathrm{N}$ utilization when animals consume rations with DDGS. Ruminally degradable protein from alfalfa may complement the high RUP content of WDGS by providing ruminally available $\mathrm{N}$ for microbial protein (MCP) synthesis. However, rations with both alfalfa and WDGS may be high in CP and may result in increased $\mathrm{N}$ excretion. The objectives of this research were to determine the effects of forage type when feeding WDGS on nutrient intake and digestibility, microbial protein synthesis, $\mathrm{N}$ utilization and excretion, and milk 
production and component yield. It was hypothesized that feeding alfalfa silage (AS) and WDGS together would result in improved MCP synthesis and milk production but also result in increased $\mathrm{N}$ excretion.

\section{MATERIALS AND METHODS}

\section{Animals and Experimental Treatments}

Eight primiparous and 20 multiparous Holsteins averaging $598 \pm 64 \mathrm{~kg}$ of BW and $99 \pm 28$ DIM were used in this experiment. Animals were blocked by parity and milk production at the beginning of the trial. The study was a replicated $4 \times 4$ Latin square, and animals were fed 1 of 4 treatments during each 21-d period. Treatments were 1) 0\% WDGS and high CS (CONT-CS); 2) 0\% WDGS and high AS (CONT-AS); 3) 25\% WDGS and high CS (WDGS-CS); and 4) 25\% WDGS and high AS (WDGS-AS) (DM basis). Ration composition and chemical composition of feedstuffs are listed in Tables 1 and 2. A single load of modified WDGS was received from Platte Valley Fuel Ethanol LLC (Central City, $\mathrm{NE}$ ) and stored in a silage bag (Up North Plastics, Cottage Grove, MN) for the duration of the study. The WDGS used in this experiment was a modified WDGS composed of dried and partially dried distillers grains and solubles, with higher DM than commonly observed for WDGS (46 vs. 30\% DM; Table 2; Schingoethe et al., 1999). Assuming DMI to be $23 \mathrm{~kg}$, rations were formulated using the Cornell-Penn-Miner model (Boston et al., 2000). High CS rations contained a ratio of 3:1 CS:AS and high AS rations contained 1:3 CS:AS. The CONT-CS and CONT-AS rations were formulated to be similar to a dairy diet fed in the Great Plains of the United States. These rations did not contain any WDGS and were largely composed of ingredients such as CS, AS, ground corn, and soybean meal. Given the high concentration of NDF and CP contained in WDGS, WDGS largely replaced CS and AS, as well as soybean meal and bypass soy. A portion of ground corn was also replaced. We chose to test differences in diets in which WDGS replaces numerous feedstuffs because this knowledge should be transposable into the field where similar approaches are used. Diets were formulated to be similar in ME and MP allowable milk (36 and $38 \mathrm{~kg}$, respectively). Additional amounts of brome hay were added to diets containing WDGS to maintain similar levels of physically effective NDF across diets $(27,23$, 25 , and $23 \%$ for CONT-CS, CONT-AS, WDGS-CS, and WDGS-AS, respectively). Cows were milked twice daily at 0730 and $1930 \mathrm{~h}$ and housed in a tie-stall barn. Animals were fed once daily at $0900 \mathrm{~h}$ for ad libitum intake and 5\% refusal. All procedures were approved by the University of Nebraska-Lincoln Animal Care and Use Committee.

\section{Sample Collection and Analysis}

Body weight and BCS (1 to 5 scale) were measured on d 20 and 21 of each period. Body condition score was measured by a single, trained individual. The scoring method used was similar to that of Wildman et al. (1982). Milk production was measured daily and milk samples were collected during 6 consecutive milkings on d 19 to 21 and were preserved using 2-bromo-2nitropropane-1,3 diol. Daily DMI and milk yield were averaged for d 15 to 21 of each period. Milk samples were analyzed for fat, true protein, and MUN (AOAC, 2000) using a B2000 Infrared Analyzer (Bentley Instruments, Chaska, MN) by Heart of America DHIA (Manhattan, KS).

Total mixed rations and feedstuffs were sampled on d 20 and 21 of each period. The Penn State Particle Separator was used to measure particle size of TMR as described by Heinrichs and Kononoff (2002). Feed samples were dried for $48 \mathrm{~h}$ at $55^{\circ} \mathrm{C}$ in a forced air oven, ground to pass through a 1-mm screen (Wiley mill, Arthur A. Thomas Co., Philadelphia, PA), and composited by sample for each period. Feed samples were analyzed for DM and ash (AOAC, 2000), N (Leco, FP-528, Leco Corp., St. Joseph, MI), and ADF and NDF (Ankom Fiber Analyzer, Ankom Technology, Fairport, NY). Heat stable $\alpha$-amylase (A3306, Sigma Chemical Co., St. Louis, MO) was included in the NDF procedure (100 $\mu \mathrm{L}$ per $0.50 \mathrm{~g}$ of sample). Additionally, TMR were analyzed for starch (Megazyme Total Starch Assay, Bray, Ireland) and ether extract (EE; AOAC, 2000).

Fecal samples were collected from the rectum of all cows at 0600 and $1800 \mathrm{~h}$ on $\mathrm{d} 18$ to 21 of each period. Fecal samples were composited for individual cows in each period, dried at $55^{\circ} \mathrm{C}$ in a forced air oven, and ground to pass through a 1-mm screen. Ground samples were analyzed for DM, N, ash, NDF, and ADF as described for feed samples. Nutrient digestibility was estimated using the marker technique with indigestible ADF (IADF; Huhtanen et al., 1994). The TMR and fecal samples were weighed into $5 \times 10 \mathrm{~cm}$ Dacron bags with $50-\mu \mathrm{m}$ pores (R510, Ankom Technology) and incubated in the rumen of a ruminally fistulated steer fed a diet containing $70 \%$ forage and $30 \%$ concentrate for $12 \mathrm{~d}$ for IADF determination. Apparent digestibility of nutrients was estimated based on the concentration of IADF in the TMR and feces, and $\mathrm{N}$ excretion in feces was calculated from the obtained $\mathrm{N}$ digestibility and $\mathrm{N}$ intake. Total digestible nutrients (TDN) were 
Table 1. Ingredient and nutrient composition of experimental treatments varying in proportion of wet distillers grains with solubles (WDGS) and forage type

\begin{tabular}{|c|c|c|c|c|}
\hline \multirow[b]{2}{*}{ Ingredient, \% DM } & \multicolumn{4}{|c|}{ Treatment $^{1}$} \\
\hline & CONT-CS & CONT-AS & WDGS-CS & WDGS-AS \\
\hline Corn silage & 31.5 & 17.4 & 18.3 & 7.9 \\
\hline Alfalfa silage & 15.8 & 34.7 & 9.2 & 15.8 \\
\hline Brome hay & 12.3 & 5.5 & 15.4 & 16.0 \\
\hline WDGS & - & - & 25.2 & 25.2 \\
\hline Ground corn & 13.8 & 23.3 & 8.4 & 14.9 \\
\hline Soy Pass ${ }^{2}$ & 5.7 & 8.2 & 3.5 & 3.1 \\
\hline Soybean meal & 9.7 & 4.6 & 2.1 & 1.3 \\
\hline Soybean hulls & 9.0 & 4.4 & 15.6 & 13.8 \\
\hline Limestone & 1.2 & 0.82 & 1.5 & 1.2 \\
\hline Magnesium oxide & 0.18 & 0.11 & 0.16 & 0.12 \\
\hline Salt & 0.06 & 0.06 & 0.10 & 0.14 \\
\hline Sodium bicarbonate & 0.72 & 0.72 & 0.51 & 0.41 \\
\hline Sel-Plex $1000^{3}$ & 0.02 & 0.02 & 0.02 & 0.02 \\
\hline Trace mineral ${ }^{4}$ & 0.04 & 0.04 & 0.04 & 0.04 \\
\hline Vitamin $\mathrm{ADE}^{5}$ & 0.12 & 0.12 & 0.12 & 0.12 \\
\hline Vitamin E & 0.02 & 0.02 & 0.02 & 0.02 \\
\hline
\end{tabular}

${ }^{1} \mathrm{CONT}-\mathrm{CS}=0 \%$ WDGS, high corn silage (CS); CONT-AS $=0 \%$ WDGS, high alfalfa silage (AS); WDGS-CS $=25 \%$ WDGS, high CS; WDGS-AS $=25 \%$ WDGS, high AS.

${ }^{2}$ LignoTech, Overland Park, KS.

${ }^{3}$ Alltech Inc., Nicholasville, KY.

${ }^{4}$ Formulated to contain $0.05 \% \mathrm{Ca}, 0.04 \% \mathrm{Fe}, 0.03 \% \mathrm{Mn}, 600 \mathrm{ppm} \mathrm{Cu}, 40 \mathrm{ppm} \mathrm{Co}$, and $80 \mathrm{ppm} \mathrm{I}$ in the total ration.

${ }^{5}$ Formulated to supply approximately $120,000 \mathrm{IU} / \mathrm{d}$ vitamin A, 24,000 IU/d vitamin D, and $800 \mathrm{IU} / \mathrm{d}$ vitamin $\mathrm{E}$ in the total ration.

calculated based on nutrient digestibilities obtained for each cow and treatment combination to account for the effect of intake on digestibility. Net energy for lactation was calculated based on TDN as described in NRC (2001). Energy balance was calculated as the difference between $\mathrm{NE}_{\mathrm{L}}$ intake $(\mathrm{Mcal} / \mathrm{d})$ and $\mathrm{NE}_{\mathrm{L}}$ output in milk and $\mathrm{NE}_{\mathrm{L}}$ required for maintenance $(0.08 \mathrm{Mcal} /$ $\left.\mathrm{BW}^{0.75}\right)$.

Urine samples were collected on all cows at 0600 and $1800 \mathrm{~h}$ on d 18 to 21 of each period. Urine was collected during urination with stimulation, using litmus paper acidified to a pH between 2 and 4 using $5 \mathrm{M} \mathrm{HCl}$, and frozen $\left(-20^{\circ} \mathrm{C}\right)$. Urine samples were thawed and composited by volume for each cow during each period. Urine samples were analyzed for N (Leco FP-528, Leco Corp.). Urinary creatinine and purine derivatives (PD) were analyzed by HPLC (Waters Corp., Milford, MA) according to the procedures of Shingfield and Offer (1998). Urinary creatinine has been validated as a marker to estimate urine volume (Valadares et al., 1999; Leonardi et al., 2003). Urinary PD, namely allantoin, uric acid, xanthine, and hypoxanthine, are widely used to estimate MCP flow to the duodenum (Gonda, 1995; Shingfield and Offer, 1998). In calculating urine volume, creatinine output was assumed to average 28 $\mathrm{mg} / \mathrm{kg}$ of BW as estimated by Whittet (2004). The

Table 2. Chemical composition (mean $\pm \mathrm{SD})$ of feed ingredients $(\mathrm{n}=8)$

\begin{tabular}{lcccc}
\hline & \multicolumn{4}{c}{ Ingredient $^{1}$} \\
\cline { 2 - 5 } Nutrient, \% of DM & CS & AS & Brome & WDGS \\
\hline DM, \% & $32.9 \pm 3.5$ & $35.3 \pm 1.4$ & $91.4 \pm 1.1$ & $46.2 \pm 3.1$ \\
OM & $95.0 \pm 0.9$ & $88.8 \pm 0.5$ & $91.4 \pm 0.5$ & $93.9 \pm 0.6$ \\
CP & $9.3 \pm 0.5$ & $21.1 \pm 0.2$ & $9.8 \pm 0.5$ & $30.2 \pm 1.1$ \\
NDF & $40.2 \pm 3.3$ & $41.5 \pm 2.7$ & $68.6 \pm 1.9$ & $32.7 \pm 2.6$ \\
Lignin & $2.7 \pm 0.4$ & $7.9 \pm 0.8$ & $6.4 \pm 1.2$ & $4.2 \pm 0.6$ \\
Starch & $33.6 \pm 3.4$ & $-5.8 \pm 0.9$ & $2.1 \pm 0.3$ & $13.5 \pm 0.8$ \\
Ether extract & $3.5 \pm 0.3$ & $3.8 \pm 0.9$ & $0.06 \pm 0.05$ \\
Ca & $0.30 \pm 0.03$ & $1.14 \pm 0.03$ & $0.29 \pm 0.03$ & $0.88 \pm 0.02$ \\
P & $0.29 \pm 0.02$ & $0.25 \pm 0.02$ & $0.28 \pm 0.02$ & $0.66 \pm 0.02$ \\
S & $0.12 \pm 0.01$ & $0.27 \pm 0.02$ & $0.13 \pm 0.02$ & \\
\hline
\end{tabular}

${ }^{1} \mathrm{CS}=$ corn silage; $\mathrm{AS}=$ alfalfa silage; Brome = brome hay; WDGS = wet distillers grains with solubles. 
Table 3. Nutrient composition and particle size of experimental treatments varying in proportion of wet distillers grains with solubles (WDGS) and forage type $(\mathrm{n}=8)$

\begin{tabular}{|c|c|c|c|c|c|}
\hline \multirow[b]{2}{*}{ Nutrient, $\%$ of DM } & \multicolumn{4}{|c|}{ Treatment $^{1}$} & \multirow[b]{2}{*}{ SEM } \\
\hline & CONT-CS & CONT-AS & WDGS-CS & WDGS-AS & \\
\hline DM, \% & 55.3 & 54.8 & 57.6 & 58.5 & 0.5 \\
\hline $\mathrm{OM}^{\prime}$ & 92.1 & 92.4 & 91.9 & 92.4 & 0.2 \\
\hline $\mathrm{CP}$ & 17.1 & 18.9 & 18.1 & 18.5 & 0.3 \\
\hline NDF & 38.6 & 34.2 & 44.1 & 43.7 & 0.4 \\
\hline Starch & 20.7 & 23.7 & 13.2 & 14.1 & 0.3 \\
\hline Ether extract & 2.5 & 2.7 & 4.5 & 4.9 & 0.1 \\
\hline $\mathrm{NFC}^{2}$ & 33.9 & 36.6 & 25.3 & 25.3 & 0.6 \\
\hline \multicolumn{6}{|c|}{ Particle size distribution ${ }^{3}$} \\
\hline$>19.0 \mathrm{~mm}$ & 8.9 & 6.9 & 7.7 & 7.7 & 0.5 \\
\hline $8.0-19.0 \mathrm{~mm}$ & 28.3 & 28.8 & 19.7 & 16.8 & 0.6 \\
\hline $1.18-8.0 \mathrm{~mm}$ & 43.2 & 46.0 & 47.4 & 48.6 & 0.6 \\
\hline$<1.18 \mathrm{~mm}$ & 19.6 & 18.3 & 25.2 & 26.9 & 0.7 \\
\hline
\end{tabular}

ratio of urinary $\mathrm{PD}$ to creatinine was used to estimate relative differences in MCP production (Shingfield and Offer, 1998). Based on estimates of urinary excretion of PD, microbial protein supply was estimated using the procedure of Chen and Gomes (1992).

\section{Statistical Analysis}

Data were analyzed as a replicated $4 \times 4$ Latin square with model effects for square, period within square, and treatment as fixed effects and cow within square as a random effect. The MIXED procedure of SAS (version 8, SAS Institute Inc., Cary, NC) was used. The linear model for this experiment is as follows:

$$
\mathrm{Y}_{\mathrm{ijkl}}=\mu+\mathrm{S}_{\mathrm{i}}+\mathrm{P}(\mathrm{S})_{\mathrm{j}(\mathrm{i})}+\mathrm{T}_{\mathrm{k}}+\mathrm{C}(\mathrm{S})_{1(\mathrm{i})}+\varepsilon_{\mathrm{ijkl}},
$$

where $Y_{\mathrm{ijkl}}$ is the dependent variable, $\mu$ is the overall mean, $S_{i}$ is the effect of square $i, P(S)_{j(i)}$ is the effect of period $j$ within square $i, T_{k}$ is the effect of treatment $k$, $\mathrm{C}(\mathrm{S})_{1(\mathrm{i})}$ is the random effect of cow 1 within square $\mathrm{i}$, and $\varepsilon_{\mathrm{ijkl}}$ is the residual error. The residual terms $\varepsilon_{\mathrm{ijkm}}$ are assumed to be normally, independently, and identically distributed with variance $\sigma_{e}^{2}$. Significance was declared at $P<0.05$ and trends at $P<0.10$. The PDIFF option was used to test treatment differences among least squares means, and all means presented are least squares means.

\section{RESULTS}

Ration nutrient content and particle size distribution of experimental treatments used are listed in Table 3. Rations containing CS had lower concentrations of CP compared with those containing AS. As WDGS replaced a portion of corn grain in the ration, NDF and ADF increased and starch and NFC decreased. Because the high concentration of EE in WDGS (Table 2), rations containing WDGS were almost 2 times higher in EE. Proportion of long particles $(>19.0 \mathrm{~mm})$ was similar among treatments because of higher inclusion of brome hay in the rations containing WDGS. The proportion of particles between 8.0 and $19.0 \mathrm{~mm}$ was lower for the rations containing WDGS but particles between 1.18 and $8.0 \mathrm{~mm}$ were similar across treatments. Both WDGS rations had a larger proportion of particles $<1.18 \mathrm{~mm}$ compared with rations without WDGS. Overall, the rations containing WDGS had similar amounts of large particles $>19.0 \mathrm{~mm}$ but had more particles $<1.18 \mathrm{~mm}$, leading to an overall smaller particle size of the ration.

Nutrient intake, amount digested, and apparent totaltract digestibility are listed in Table 4 . There was an effect of treatment $(P<0.01)$ for DMI, with CONT-CS $(22.5 \mathrm{~kg} / \mathrm{d})$ having the lowest intake, whereas CONTAS $(24.6 \mathrm{~kg} / \mathrm{d})$, WDGS-CS $(24.6 \mathrm{~kg} / \mathrm{d})$, and WDGSAS $(24.8 \mathrm{~kg} / \mathrm{d})$ were similar. There were no effects of treatment on DM, OM, NDF, ADF, or N digestibility, averaging $59.6 \pm 1.6,62.3 \pm 1.5,40.1 \pm 3.2,35.1 \pm$ 2.9 , and $58.6 \pm 2.1 \%$, respectively. Rations containing WDGS had higher $(P<0.01)$ EE digestibility $(75.0$ vs. $66.0 \%)$ and lower $(P<0.01)$ NFC digestibility $(89.3$ vs. $92.2 \%$ ) than rations not containing WDGS. Total digestible nutrient content was not different among treatments, averaging $53.6 \pm 1.7 \%$; however, TDN intake was greater $(P=0.01)$ for CONT-AS, WDGS-CS, and WDGS-AS compared with CONT-CS (13.5, 13.2, 13.3 vs. $11.7 \mathrm{~kg} / \mathrm{d}$ ) because of increased DMI. There was no effect of treatment on concentration of $\mathrm{NE}_{\mathrm{L}}$ in 
Table 4. Effect of proportion of wet distillers grains with solubles (WDGS) and forage type on nutrient intake and total-tract digestibility

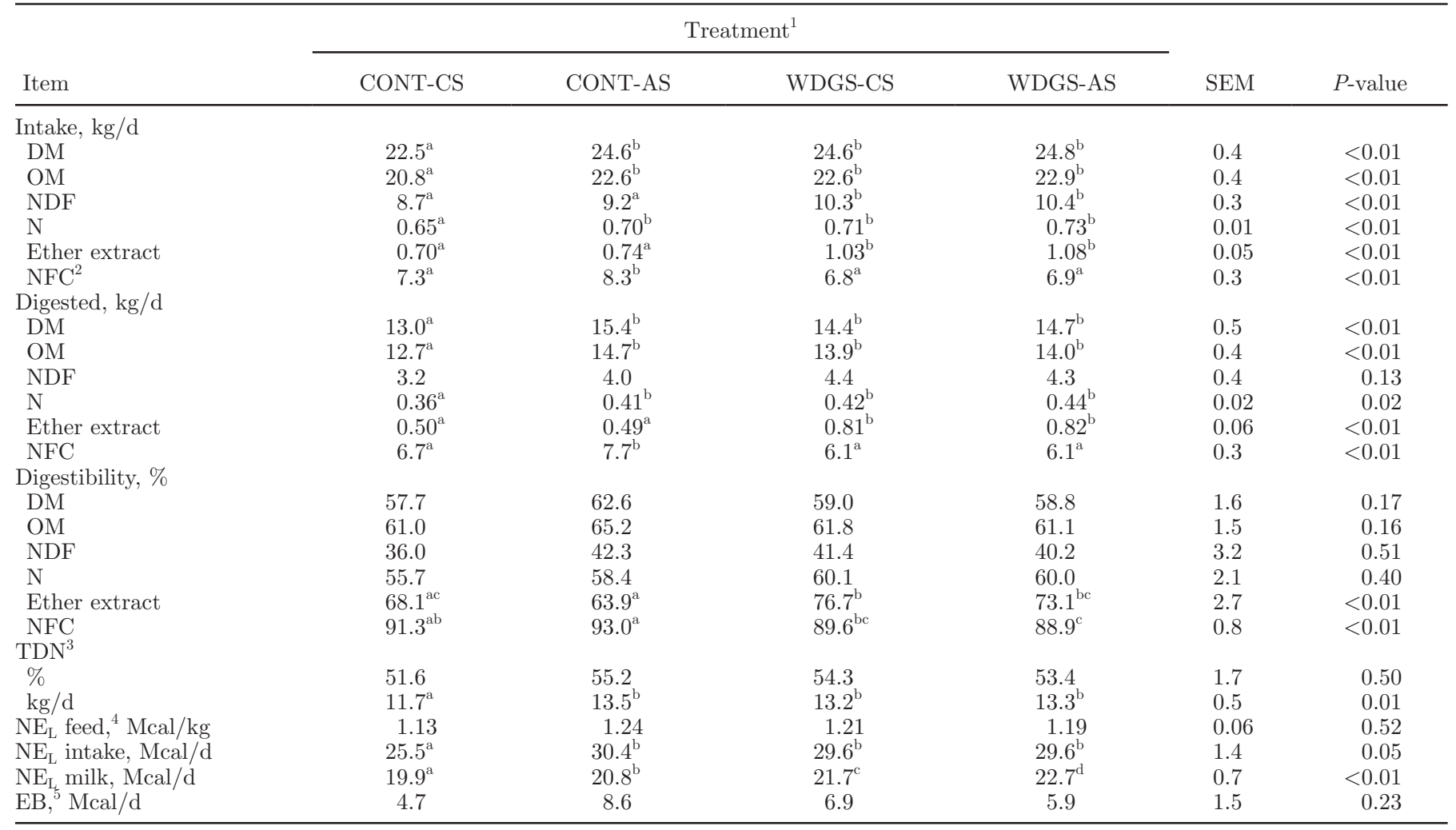

${ }^{\mathrm{a}-\mathrm{d}}$ Values in the same row with different superscripts differ $(P<0.05)$.

${ }^{1}$ CONT-CS $=0 \%$ WDGS, high corn silage (CS); CONT-AS $=0 \%$ WDGS, high alfalfa silage (AS); WDGS-CS $=25 \%$ WDGS, high CS; WDGS$\mathrm{AS}=25 \%$ WDGS, high AS.

${ }^{2} \mathrm{NFC}=100-(\mathrm{CP}+\mathrm{NDF}+$ ash + ether extract $)$.

${ }^{3}$ Total digestible nutrients adjusted for actual intake: $\mathrm{TDN}=\mathrm{tdNFC}+\mathrm{tdCP}+(\mathrm{td}$ ether extract $\times 2.25)+\mathrm{tdNDF}-7(\mathrm{NRC}, 2001) ; \mathrm{td}=$ total digestible.

${ }^{4} \mathrm{NE}_{\mathrm{L}}$ at actual intake based on TDN (NRC, 2001).

${ }^{5}$ Energy balance $=\mathrm{NE}_{\mathrm{L}}$ intake $(\mathrm{Mcal} / \mathrm{d})-\mathrm{NE}_{\mathrm{L}}$ milk $(\mathrm{Mcal} / \mathrm{d})-0.08 \mathrm{BW}^{0.75}$.

the feed, which averaged $1.19 \pm 0.06 \mathrm{Mcal} / \mathrm{kg}$. There was an effect of treatment $(P=0.05)$ on calculated $\mathrm{NE}_{\mathrm{L}}$ intake following the observed difference for DMI, with animals on the CONT-CS treatment consuming less energy than those on CONT-AS, WDGS-CS, and WDGS-AS (25.5 vs. 30.4, 29.7 and $29.5 \mathrm{Mcal} / \mathrm{d}$ ). There was an effect of treatment $(P<0.01)$ on calculated $\mathrm{NE}_{\mathrm{L}}$ secreted in milk with animals in the WDGS-AS group secreting the most energy in milk, followed by animals in the WDGS-CS, CONT-AS, and CONT-CS groups (22.7 vs. 21.7 vs. 20.8 vs. $19.9 \mathrm{Mcal} / \mathrm{d}$, respectively). There was no effect of treatment on energy balance, which averaged $6.5 \pm 1.5 \mathrm{Mcal} / \mathrm{d}$.

Excretion of PD and estimated ruminal MCP synthesis is listed in Table 5. There were no effects of treatment on excretion of creatinine, allantoin, uric acid, or xanthine, which averaged $154.9 \pm 2.2,276.2 \pm 11.9$, $38.3 \pm 1.9$, and $20.1 \pm 13.4 \mathrm{mmol} / \mathrm{d}$, respectively. There was an effect of treatment $(P<0.01)$ on hypoxanthine excretion, with WDGS-AS resulting in the greatest output, followed by WDGS-CS, and then CONT-CS and CONT-AS (181.8 vs. 149.8 vs. 37.6 vs. $47.5 \mathrm{mmol} / \mathrm{d}$ ). Total PD excretion was also greatest $(P>0.01)$ for WDGS-AS, followed by WDGS-CS, and then CONTCS and CONT-AS (507.2 vs. 466.7 vs. 289.0 and 392.0 $\mathrm{mmol} / \mathrm{d}$, respectively). Microbial protein flow, which is calculated from total PD excretion observed, was highest for WDGS-AS, followed by WDGS-CS, and then CONT-CS and CONT-AS (2,189.9 vs. 1,996.2 vs. $1,627.0$ and $1,640.0 \mathrm{~g} / \mathrm{d}$ ).

Nitrogen utilization is listed in Table 6. There was an effect of treatment $(P<0.01)$ on $\mathrm{N}$ intake with animals in the CONT-CS treatment having lower $\mathrm{N}$ intake than those in CONT-AS, WDGS-CS, and WDGS-AS (646.4 vs. $702.9,707.0$, and $731.9 \mathrm{~g} / \mathrm{d}$, respectively). Fecal $\mathrm{N}$ excretion was not affected by treatment, averaging $287.1 \pm 14.7 \mathrm{~g} / \mathrm{d}$, whereas feeding WDGS-CS and WDGS-AS lowered $(P<0.01)$ urinary $\mathrm{N}$ excre- 
Table 5. Effect of proportion of wet distillers grains with solubles (WDGS) and forage type on urinary purine derivative excretion and estimated ruminal microbial protein synthesis

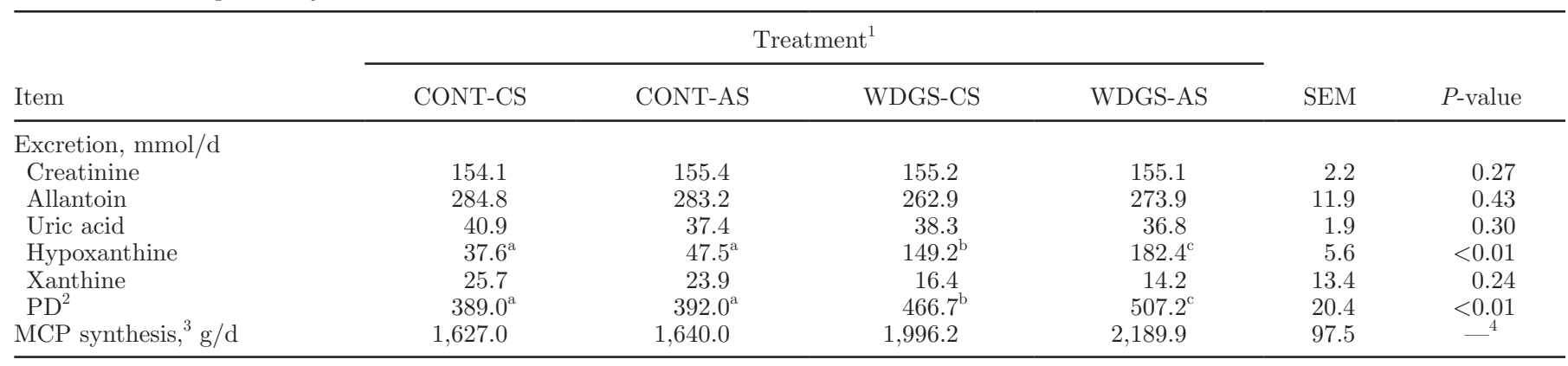

${ }^{\mathrm{a}-\mathrm{c}}$ Values in the same row with different superscripts differ $(P<0.05)$.

${ }^{1} \mathrm{CONT}-\mathrm{CS}=0 \%$ WDGS, high corn silage (CS); CONT-AS $=0 \%$ WDGS, high alfalfa silage (AS); WDGS-CS $=25 \%$ WDGS, high CS; WDGS$\mathrm{AS}=25 \%$ WDGS, high AS.

${ }^{2}$ Purine derivatives $=$ allantoin + uric acid + hypoxanthine + xanthine.

${ }^{3}$ Microbial protein synthesis based on purine derivative excretion as described by Chen and Gomes (1992).

${ }^{4}$ Statistical test of effect of treatment on ruminal MCP synthesis was not conducted because MCP was calculated based on excretion of PD (Firkins et al., 2006).

tion compared with CONT-CS and CONT-AS (255.9 and 248.1 vs. 321.7 and $315.1 \mathrm{~g} / \mathrm{d})$. Similar fecal N but reduced urinary $\mathrm{N}$ excretion resulted in reduced $(P=$ 0.02 ) manure $\mathrm{N}$ (fecal and urinary $\mathrm{N}$ ) excretion for rations containing WDGS. Milk N secretion (milk protein $\mathrm{N}$ and MUN) was affected by treatment $(P<0.01)$ with treatment WDGS-AS resulting in the greatest milk $\mathrm{N}$ secretion, followed by WDGS-CS, CONT-AS, and CONT-CS (159.4 vs. 153.1 vs. 144.0 vs. $137.0 \mathrm{~g} / \mathrm{d}$, respectively). Calculated retained $\mathrm{N}$ was greater $(P<$ $0.01)$ for WDGS-CS and WDGS-AS compared with
CONT-CS and CONT-AS (15.4 and 32.5 vs. -94.7 and $-47.4 \mathrm{~g} / \mathrm{d}$, respectively). When expressed as a percentage of $\mathrm{N}$ intake, $\mathrm{N}$ excretion followed similar patterns as mass balance. Proportion of $\mathrm{N}$ intake excreted in feces and milk was similar among treatments, whereas urinary and manure $\mathrm{N}$ were reduced and retained $\mathrm{N}$ was increased for rations containing WDGS compared with control.

Milk production and components are listed in Table 7. Milk yield was greater $(P<0.01)$ for WDGS-CS and WDGS-AS than for CONT-CS and CONT-AS (31.5

Table 6. Effect of proportion of wet distillers grains with solubles (WDGS) and forage type on nitrogen utilization

\begin{tabular}{|c|c|c|c|c|c|c|}
\hline \multirow[b]{2}{*}{$\mathrm{N}$ utilization } & \multicolumn{4}{|c|}{ Treatment $^{1}$} & \multirow[b]{2}{*}{ SEM } & \multirow[b]{2}{*}{$P$-value } \\
\hline & CONT-CS & CONT-AS & WDGS-CS & WDGS-AS & & \\
\hline \multicolumn{7}{|l|}{ Mass, g/d } \\
\hline Intake N & $646.4^{\mathrm{a}}$ & $702.9^{\mathrm{b}}$ & $707.0^{\mathrm{b}}$ & $731.9^{\mathrm{b}}$ & 14.7 & $<0.01$ \\
\hline Fecal N & 282.4 & 291.3 & 282.8 & 291.9 & 14.7 & 0.93 \\
\hline Urinary N & $321.7^{\mathrm{a}}$ & $315.1^{\mathrm{a}}$ & $255.9^{\mathrm{b}}$ & $248.1^{\mathrm{b}}$ & 14.6 & $<0.01$ \\
\hline Manure $\mathrm{N}^{2}$ & $604.1^{\mathrm{a}}$ & $606.3^{\mathrm{a}}$ & $537.4^{\mathrm{b}}$ & $540.2^{\mathrm{b}}$ & 21.1 & 0.02 \\
\hline Milk $N^{3}$ & $137.0^{\mathrm{a}}$ & $144.0^{\mathrm{b}}$ & $153.1^{\mathrm{c}}$ & $159.4^{\mathrm{d}}$ & 4.2 & $<0.01$ \\
\hline Retained $\mathrm{N}^{4}$ & $-94.7^{\mathrm{a}}$ & $-47.4^{\mathrm{a}}$ & $15.4^{\mathrm{b}}$ & $32.5^{\mathrm{b}}$ & 24.3 & $<0.01$ \\
\hline Productive $\mathrm{N}^{5}$ & $42.3^{\mathrm{a}}$ & $96.6^{\mathrm{a}}$ & $167.6^{\mathrm{b}}$ & $191.9^{\mathrm{b}}$ & 23.9 & $<0.01$ \\
\hline \multicolumn{7}{|l|}{$\mathrm{N}$ intake, $\%$} \\
\hline Fecal N & 44.4 & 41.6 & 39.9 & 40.0 & 2.1 & 0.40 \\
\hline Urinary $\mathrm{N}$ & $49.9^{\mathrm{a}}$ & $45.5^{\mathrm{a}}$ & $36.6^{\mathrm{b}}$ & $34.2^{\mathrm{b}}$ & 2.5 & $<0.01$ \\
\hline Manure N & $94.3^{\mathrm{a}}$ & $87.1^{\mathrm{a}}$ & $76.5^{\mathrm{b}}$ & $74.3^{\mathrm{b}}$ & 3.5 & $<0.01$ \\
\hline Milk N & 21.4 & 20.6 & 21.6 & 21.9 & 0.5 & 0.12 \\
\hline Retained N & $-15.7^{\mathrm{a}}$ & $-7.7^{\mathrm{a}}$ & $1.9^{\mathrm{b}}$ & $3.9^{\mathrm{b}}$ & 3.8 & $<0.01$ \\
\hline Productive N & $5.7^{\mathrm{a}}$ & $12.9^{\mathrm{a}}$ & $23.5^{\mathrm{b}}$ & $25.8^{\mathrm{b}}$ & 3.5 & $<0.01$ \\
\hline
\end{tabular}

${ }^{\mathrm{a}-\mathrm{d}}$ Values in the same row with different superscripts differ $(P<0.05)$.

${ }^{1} \mathrm{CONT}-\mathrm{CS}=0 \%$ WDGS, high corn silage (CS); CONT-AS $=0 \%$ WDGS, high alfalfa silage (AS); WDGS-CS $=25 \%$ WDGS, high CS; WDGS$\mathrm{AS}=25 \%$ WDGS, high AS.

${ }^{2}$ Manure $\mathrm{N}=$ fecal $\mathrm{N}+$ urinary $\mathrm{N}$.

${ }^{3}$ Milk $\mathrm{N}=$ (milk protein yield, g/d/6.38) + MUN, g/d.

${ }^{4}$ Apparently retained $\mathrm{N}=$ intake $\mathrm{N}-($ manure $\mathrm{N}+$ milk $\mathrm{N})$.

${ }^{5}$ Productive $\mathrm{N}=$ milk $\mathrm{N}+$ retained $\mathrm{N}$. 
Table 7. Effects of proportion of wet distillers grain with solubles (WDGS) and forage type on milk production and components

\begin{tabular}{|c|c|c|c|c|c|c|}
\hline Measurement & \multicolumn{4}{|c|}{ Treatment $^{1}$} & SEM & $P$-value \\
\hline Milk, $\mathrm{kg} / \mathrm{d}$ & $28.5^{\mathrm{a}}$ & $29.4^{\mathrm{a}}$ & $31.5^{\mathrm{b}}$ & $32.4^{\mathrm{b}}$ & 0.7 & $<0.01$ \\
\hline Fat, $\%$ & 3.75 & 3.75 & 3.63 & 3.69 & 0.11 & 0.37 \\
\hline Fat, kg/d & $1.06^{\mathrm{a}}$ & $1.10^{\mathrm{ab}}$ & $1.14^{\mathrm{bc}}$ & $1.20^{\mathrm{c}}$ & 0.05 & $<0.01$ \\
\hline Protein, \% & 3.05 & 3.10 & 3.09 & 3.12 & 0.04 & 0.08 \\
\hline $\mathrm{BW}, \mathrm{kg}$ & 622 & 628 & 627 & 626 & 9 & 0.27 \\
\hline $\mathrm{BCS}$ & 3.13 & 3.21 & 3.25 & 3.07 & 0.11 & 0.09 \\
\hline
\end{tabular}

${ }^{\mathrm{a}-\mathrm{d}}$ Values in the same row with different superscripts differ $(P<0.05)$.

${ }^{1}$ CONT-CS $=0 \%$ WDGS, high corn silage (CS); CONT-AS $=0 \%$ WDGS, high alfalfa silage (AS); WDGS-CS $=25 \%$ WDGS, high CS; WDGS$\mathrm{AS}=25 \%$ WDGS, high AS.

${ }^{2}$ Feed conversion $=4 \% \mathrm{FCM} / \mathrm{DMI}$.

and 32.4 vs. 28.5 and $29.4 \mathrm{~kg} / \mathrm{d})$. There were also treatment effects $(P<0.01)$ on $4 \%$ FCM, with WDGS-AS resulting in the greatest yield, followed by WDGS-CS, and then CONT-CS and CONT-AS (30.8 vs. 29.6 vs. 27.2 and $28.3 \mathrm{~kg} / \mathrm{d})$. Milk fat yield was greatest $(P$ $<0.01)$ for WDGS-AS $(1.20 \mathrm{~kg} / \mathrm{d})$, intermediate for CONT-AS $(1.10 \mathrm{~kg} / \mathrm{d})$ and WDGS-CS $(1.14 \mathrm{~kg} / \mathrm{d})$, and lowest for CONT-CS $(1.06 \mathrm{~kg} / \mathrm{d})$. Milk protein yield was greatest $(P<0.01)$ for WDGS-AS followed by WDGS-CS, CONT-AS, and CONT-CS (1.00 vs. 0.96 vs. 0.91 vs. $0.86 \mathrm{~kg} / \mathrm{d}$, respectively). Feed conversion (4\% FCM/DMI) was improved $(P<0.01)$ for CONTCS (1.21), WDGS-CS (1.21), and WDGS-AS (1.24) compared with CONT-AS (1.15). Milk urea N and BW were not different among treatments, averaging $15.0 \pm$ $0.4 \mathrm{mg} / \mathrm{dL}$ and $626 \pm 9 \mathrm{~kg}$.

\section{DISCUSSION}

\section{Ration Particle Size}

One of the concerns with replacing forages with nonforage fiber sources such as WDGS is the reduction in ration particle size and effective fiber, both of which increase the risk for acidosis, displaced abomasum, and milk fat depression (Pereira et al., 1999). Heinrichs and Kononoff (2002) suggested that rations should contain 2 to $8 \%$ on the top screen $(>19.0 \mathrm{~mm}), 30$ to $50 \%$ on the second screen ( 8.0 to $19.0 \mathrm{~mm}$ ), 30 to $50 \%$ on the third screen ( 1.18 to $8.0 \mathrm{~mm})$, and $<20 \%$ in the bottom pan $(<1.18 \mathrm{~mm})$. All experimental rations in the current experiment fell within these ranges for particles $>19.0 \mathrm{~mm}$ and 1.18 to $8.0 \mathrm{~mm}$, but did not meet the minimum recommendation for particles 8.0 to $19.0 \mathrm{~mm}$ (17 to 29\%). In addition, rations containing WDGS had greater than $20 \%$ of the TMR $<1.18 \mathrm{~mm}$. In this experiment, it did appear that rations with WDGS had a finer particle size; however, there were no detected incidences of milk fat depression, displaced abomasum, or other digestive disorders. This suggests that effective fiber was adequate for all treatments.

\section{Nutrient Intake and Digestibility}

The inclusion of WDGS in a ration may have been more important in determining the effect of treatment DMI than forage type. Dry matter intake decreased when the proportion of CS was greater than AS in the control rations but was unaffected by forage type when WDGS was included. When the proportion of total forage in the ration decreased for rations containing WDGS, forage type may have been less important in the regulation of DMI, resulting in no difference in rations containing WDGS with differing proportions of AS and CS. Separately, both forage type and distillers grains with solubles have been shown to affect DMI. Brito and Broderick (2006) observed a linear decrease in DMI as CS replaced AS in rations containing $50 \%$ forage, similar to the relationship between the control rations in this experiment. Increased DMI has been observed for several studies feeding both WDGS and DDGS to lactating cows (Anderson et al., 2006; Janicek et al., 2008). The response of DMI to forage type and distillers grains may be related to ruminal NDF digestibility (NDFD). Getachew et al. (2004) found in vitro NDFD for alfalfa silage to be higher than corn silage (49 vs. $42 \%$ ), and DDGS showed even greater NDFD (68\%). This indicates that in vitro NDF digestion may be improved when there is a higher proportion of AS than CS in a ration as well as when WDGS replaces a portion of AS or CS. Although improved total-tract NDFD was observed for a ration containing 30\% DM 
corn milling co-products in a previous experiment (Gehman and Kononoff, 2008), apparent total-tract NDFD was not different among treatments for the current experiment. Dry matter intake response may have been mediated by varying levels of grass hay included in the rations in the current experiment. Although the total forage level was similar for CONT-CS and CONT-AS (60 and $58 \% \mathrm{DM}$ ), brome hay inclusion was higher for CONT-CS than CONT-AS (12.3 vs. $5.5 \%$ DM). Grass silage-based rations have been shown to reduce DMI compared with AS-based rations because of fill effects mediated by slower degradation of NDF in the rumen (Voelker Linton and Allen, 2008). Both DM and NDF digestibility was numerically reduced for CONTCS compared with CONT-AS, potentially because of higher inclusion of grass hay, resulting in lower DMI for CONT-CS. Varying levels of grass hay may also explain why there was no difference in DMI between CONT-AS and rations containing WDGS. Although other studies observed an increase in DMI when DDGS replaced a portion of forage (Janicek et al., 2008), higher grass hay inclusion in rations containing WDGS (15.4 and 16.0\% DM) may have limited DMI even though total forage levels were reduced compared with CONT-AS (43 and 40 vs. $58 \% \mathrm{DM}$ ).

Intake of TDN and $\mathrm{NE}_{\mathrm{L}}$ was limited by DMI and was lowest for the diet containing CS but no WDGS. Calculated $\mathrm{NE}_{\mathrm{L}}$ concentration of feed was lowest for CONT-CS, resulting in reduced $\mathrm{NE}_{\mathrm{L}}$ intake for that treatment. Although animals consuming CONT-CS had reduced $\mathrm{NE}_{\mathrm{L}}$ intake, they also had reduced $\mathrm{NE}_{\mathrm{L}}$ secretion in milk, resulting in similar energy balance to the remaining treatments (averaging $6.5 \pm 1.5 \mathrm{Mcal} / \mathrm{d}$ ). Cows consuming CONT-AS had higher $\mathrm{NE}_{\mathrm{L}}$ intake, numerically higher 4\% FCM, and similar energy balance. Compared with animals consuming rations with WDGS, animals consuming control rations consumed similar or reduced $\mathrm{NE}_{\mathrm{L}}$ but secreted less energy in milk. This suggests that $\mathrm{NE}_{\mathrm{L}}$ consumed was better utilized for milk production by animals consuming rations containing WDGS compared with control animals.

\section{Urinary PD Excretion and MCP Synthesis}

The concentration of hypoxanthine was higher for rations that included WDGS, as also observed by Janicek et al. (2008) and Kelzer (2008). The central assumption when using $\mathrm{PD}$ as an MCP marker is the complete degradation of feed purines in the rumen and the absorption of purines solely of microbial origin (Chen and Gomes, 1992). Yeast cells of the strain Saccharomyces cerevisiae are often used to ferment starch into ethanol and are present in resulting co-products (Zhan et al., 2003). The yeast cell may contain purines that may not be degraded in the rumen, potentially resulting in increased hypoxanthine excretion and elevated MCP estimations. Consequently, caution should be taken when interpreting MCP synthesis when estimated by urinary PD excretion.

In animals consuming WDGS, increased excretion of urinary PD suggests that improved rumen conditions may have stimulated rumen microbial growth and ultimately allowed for increased MCP synthesis. Ruminally available energy is generally the most limiting nutrient for MCP synthesis (Clark et al., 1992). In this study, some of the energy in starch from corn was replaced with energy from NDF in WDGS. Despite low starch levels for the WDGS rations, MCP synthesis was improved, indicating that WDGS rations provided the rumen microbes with sufficient energy to support growth despite lower levels of starch. Reduced starch content and intake has been shown to increase rumen $\mathrm{pH}$ (Oba and Allen, 2003), and improved rumen $\mathrm{pH}$ has been shown to stimulate MCP synthesis (Calsamiglia et al., 2008). The NRC (2001) model predicts MCP synthesis based on TDN; however, the relationship between TDN and MCP synthesis for this experiment was inconsistent. For rations with WDGS, a 12 to $13 \%$ increase in kilograms of TDN and DM apparently digested corresponded to 22 to $34 \%$ increase in MCP. However, for rations not containing WDGS, TDN and apparently digested DM were not correlated with increased MCP synthesis. The large differences in MCP synthesis and lack of differences in TDN among treatments indicates that other nutritional factors, such as the influence of rate of carbohydrate degradation in the rumen and starch intake on rumen $\mathrm{pH}$, may have influenced $\mathrm{MCP}$ to a greater degree than TDN.

\section{Nitrogen Utilization}

Total N excretion was reduced for animals consuming rations with WDGS due to an approximately $20 \%$ decrease in urinary $\mathrm{N}$ excretion and more $\mathrm{N}$ was utilized for production. A major source of urinary $\mathrm{N}$ originates from $\mathrm{N}$ losses from the rumen (Tamminga, 1992), and the observed decrease in urinary $\mathrm{N}$ for WDGS rations may be because of reduced ruminal $\mathrm{N}$ losses. In the current experiment, MCP synthesis was estimated to be 20 to $30 \%$ higher for rations with WDGS, which may have allowed the rumen microbes to utilize more ammonia in the rumen. Ammonia not utilized for microbial growth is absorbed by the ruminal epithelium into blood, ammonia is converted to urea in the liver, and urea is excreted in urine (Van Soest, 1994). Broderick et al. (2008) observed a reduction in urinary $\mathrm{N}$ excretion when MCP synthesis was increased despite increased $\mathrm{N}$ intake, similar to the current experiment. 
Another major source of urinary $\mathrm{N}$ is incomplete conversion of absorbed AA into productive uses such as tissue and milk protein synthesis (Tamminga, 1992). Assuming reduced rumen $\mathrm{N}$ losses, urinary $\mathrm{N}$ excretion may have been reduced for WDGS rations because of improved conversion of absorbed AA into milk and tissue protein. In the current study, milk $\mathrm{N}$ was increased from 141 to $156 \mathrm{~g} / \mathrm{d}$ and retained $\mathrm{N}$ was increased from -71 to $24 \mathrm{~g} / \mathrm{d}$ for rations with WDGS. This may be the result of increased utilization of AA for productive uses (milk protein secretion and retention in tissue) and reduced deamination and urinary excretion of $\mathrm{N}$ from excess AA. Together these observations may indicate the protein provided by the WDGS may be of good quality and may contribute to meeting the animal's requirements for milk protein secretion as well as maintenance. In contrast to the reduced urinary $\mathrm{N}$ excretion for rations with WDGS, MUN concentration was not different among rations. Researchers have found a positive correlation between urinary $\mathrm{N}$ excretion and MUN (Kauffman and St-Pierre, 2001; Nennich et al., 2006). However, others have observed differences in urinary $\mathrm{N}$ excretion without a concurrent reflection in MUN (Ipharraguerre and Clark, 2005; Broderick et al., 2008). Fecal N excretion was similar for all treatments despite differences in $\mathrm{N}$ intake. Others have found $\mathrm{N}$ to be excreted equally in feces and urine up to $400 \mathrm{~g} / \mathrm{d}$ of $\mathrm{N}$ intake, with excess $\mathrm{N}$ excreted primarily in urine (Castillo et al., 2001; Kebreab et al., 2001). In this case, similar fecal $\mathrm{N}$ excretion was observed for all treatments regardless of $\mathrm{N}$ intake, whereas urinary $\mathrm{N}$ excretion was reduced for WDGS rations despite increased $\mathrm{N}$ intake. Practically, partitioning of $\mathrm{N}$ between feces and urine is important not only because it represents efficiency of $\mathrm{N}$ utilization but also because of the environmental implications of urinary $\mathrm{N}$ excretion.

\section{Milk Production and Components}

Production of $4 \%$ FCM and milk components was improved by the inclusion of WDGS and AS. Some previous studies have demonstrated an increase in milk production when cows were fed rations up to $20 \%$ WDGS or DDGS (Anderson et al., 2006) or up to $30 \%$ DDGS (Janicek et al., 2008) compared with a zero control, with no negative effects on milk components. It bears noting that rations with WDGS had low starch and NFC content compared with control rations (13.6 and 25.3 vs. 22.2 and $35.3 \% \mathrm{DM}$ ) while producing more $4 \%$ FCM. Nocek (1997) recommended limiting NFC in dairy rations to 30 to $40 \% \mathrm{DM}$ to avoid acidosis. Nutritionists attempt to maximize NFC to maximize energy intake and milk production and only limit starch inclusion because of the risk of acidosis. In this study, rations lower than the recommended NFC levels allowed for similar $\mathrm{NE}_{\mathrm{L}}$ intake while improving milk production. Energy intake may only partly explain the observed increase in milk production. Increased milk production for rations with WDGS may also have been related to differences in supply of MP. Raggio et al. (2004) observed an increase in milk production when animals consumed rations resulting in increased MP flow but similar energy intake. Microbial protein flow was estimated to be higher for rations with WDGS and $\mathrm{AS}$, and the resulting differences in MP flow may have supported increased 4\% FCM and yield of milk protein. This supports one of the hypotheses of the experiment that RDP from AS may improve MCP flow and complement RUP from WDGS, potentially increasing overall MP flow and resulting in increased milk production.

\section{CONCLUSIONS}

Including WDGS in rations for dairy cattle improved calculated MCP synthesis, 4\% FCM production, protein yield, and feed efficiency compared with control rations. Additionally, including a greater proportion of AS than CS in rations with WDGS further improved milk production and protein yield, suggesting a complementary relationship between WDGS and AS. Nitrogen excretion was reduced for the WDGS rations, principally by a reduction in urinary $\mathrm{N}$ excretion. Forage type did not appear to affect $\mathrm{N}$ excretion in either control or WDGS rations. This research demonstrated WDGS can be fed at $25 \%$ with $\mathrm{AS}$ and result in improved milk production and protein yield while reducing $\mathrm{N}$ excretion and the environmental impact of milk production.

\section{ACKNOWLEDGMENTS}

The authors thank the Nebraska Corn Board (Lincoln) for financial support for this experiment. We also thank the employees at the University of Nebraska Dairy Research Unit in Mead, Nebraska, for care of the experimental animals. Many thanks to J. Kelzer, K. Machacek, E. Castillo-Lopez, A. Geis, C. Heine, and Z. Alger (University of Nebraska-Lincoln) for assistance in collecting samples.

\section{REFERENCES}

Anderson, J. L., D. J. Schingoethe, K. F. Kalscheur, and A. R. Hippen. 2006. Evaluation of dried and wet distillers grains included at two concentrations in the diets of lactating dairy cows. J. Dairy Sci. 89:3133-3142.

AOAC. 2000. Official Methods of Analysis. Vol. 1 and 2. 17th ed. AOAC International, Gaithersburg, MD.

Boston, R. C., D. G. Fox, C. J. Sniffen, R. Janczewski, R. Munsen, and W. Chalupa. 2000. The conversion of a scientific model describing dairy cow nutrition and production to an industry tool: The CPM 
Dairy project. Pages 361-377 in Modelling Nutrient Utilization in Farm Animals. J.P. McNamara, J. France, and D. Beever, ed. CABI Publishing, Oxford, UK.

Brito, A. F., and G. A. Broderick. 2006. Effect of varying dietary ratios of alfalfa silage to corn silage on production and nitrogen utilization in lactating dairy cows. J. Dairy Sci. 89:3924-3938.

Broderick, G. A. 2003. Effects of varying dietary protein and energy levels on the production of lactating dairy cows. J. Dairy Sci. $86: 1370-1381$.

Broderick, G. A., M. J. Stevenson, R. A. Patton, N. E. Lobos, and J. J. Olmos Colmenero. 2008. Effect of supplementing rumen-protected methionine on production and nitrogen excretion in lactating dairy cows. J. Dairy Sci. 91:1092-1102.

Calsamiglia, S., P. W. Cardozo, A. Ferret, and A. Bach. 2008. Changes in rumen microbial fermentation are due to a combined effect of type of diet and pH. J. Anim. Sci. 86:702-711.

Castillo, A. R., E. Kebreab, D. E. Beever, J. H. Barbi, J. D. Sutton, H. C. Kirby, and J. France. 2001. The effect of protein supplementation on nitrogen utilization in lactating dairy cows fed grass silage diets. J. Anim. Sci. 79:247-253

Chen, X. B., and M. J. Gomes. 1992. Estimation of microbial protein supply to sheep and cattle based on urinary excretion of purine derivatives - an overview of the technical details. Rowett Research Institute, Bucksburn, Aberdeen, UK.

Clark, J. H., T. H. Klusmeyer, and M. R. Cameron. 1992. Microbial protein synthesis and flows of nitrogen fractions to the duodenum of dairy cows. J. Dairy Sci. 75:2304-2323.

Firkins, J. L., A. N. Hristov, M. B. Hall, G. A. Varga, and N. R. StPierre. 2006. Integration of ruminal metabolism in dairy cattle. J. Dairy Sci. 89:E31-E51.

Gehman, A. M., and P. J. Kononoff. 2008. Feeding two corn milling coproducts to dairy cattle: Nutrient digestibility, purine derivative excretion, and nitrogen utilization. J. Dairy Sci. 91(E-Suppl. 1):533. (Abstr.)

Getachew, G., P. H. Robinson, E. J. DePeters, and S. J. Taylor. 2004. Relationships between chemical composition, dry matter degradation and in vitro gas production of several ruminant feeds. Anim. Feed Sci. Technol. 111:57-71.

Gonda, H. L. 1995. Nutritional status of ruminants determined from excretion and concentration of metabolites in body fluids. $\mathrm{PhD}$ Diss. Swedish Univ. Agricultural Sciences. Dep. Anim. Nutr. Management, Uppsala.

Groff, E. B., and Z. Wu. 2005. Milk production and nitrogen excretion of dairy cows fed different amounts of protein and varying proportion of alfalfa and corn silage. J. Dairy Sci. 88:3619-3632.

Heinrichs, A. J., and P. J. Kononoff. 2002. Evaluating particle size of forages and TMRs using the New Penn State Forage Particle Separator. Tech. Bull. DAS 02-42. Pennsylvania State Univ., College Agric. Sci., Cooperative Ext., University Park.

Huhtanen, P., K. Kaustell, and S. Jaakkola. 1994. The use of internal markers to predict total digestibility and duodenal flow of nutrients in cattle given six different diets. Anim. Feed Sci. Technol. 48:211-227.

Ipharraguerre, I. R., and J. H. Clark. 2005. Varying protein and starch in the diet of dairy cows: II. Effects on performance and nitrogen utilization for milk production. J. Dairy Sci. 88:2556-2570.

Janicek, B. N., P. J. Kononoff, A. M. Gehman, and P. H. Doane. 2008. The effect of feeding dried distillers grains plus soluble on milk production and excretion of urinary purine derivatives. J. Dairy Sci. 91:3544-3553.

Kauffman, A. J., and N. R. St-Pierre. 2001. The relationship of milk urea nitrogen to urine nitrogen excretion in Holstein and Jersey cows. J. Dairy Sci. 84:2284-2294.

Kebreab, E., J. France, D. E. Beever, and A. R. Castillo. 2001. Nitrogen pollution by dairy cows and its mitigation by dietary manipulation. Nutr. Cycl. Agroecosyst. 60:275-285.
Kelzer, J. M. 2008. Effects of feeding three types of corn milling coproducts on milk production and ruminal fermentation of lactating Holstein cattle. MS thesis. Univ. Nebraska, Lincoln.

Kleinschmit, D. H., D. J. Schingoethe, A. R. Hippen, and K. F. Kalscheur. 2007. Dried distillers grains plus solubles with corn silage or alfalfa hay as the primary forage source in dairy cow diets. J. Dairy Sci. 90:5587-5599.

Klopfenstein, T. J., G. E. Erickson, and V. R. Bremer. 2008. Use of distillers by-products in the beef cattle feeding industry. J. Anim. Sci. 86:1223-1231.

Leonardi, C., M. Stevenson, and L. E. Armentano, 2003. Effect of two levels of crude protein and methionine supplementation on performance of dairy cows. J. Dairy Sci. 86:4033-4042.

NRC. 2001. Nutrient Requirements of Dairy Cattle. 7th rev. ed. National Academy Press, Washington, DC.

Nennich, T. D., J. H. Harrison, L. M. VanWieringen, N. R. St-Pierre, R. L. Kincaid, M. A. Wattiaux, D. L. Davidson, and E. Block. 2006. Prediction and evaluation of urine and urinary nitrogen and mineral excretion from dairy cattle. J. Dairy Sci. 89:353-364.

Nocek, J. E. 1997. Bovine acidosis: Implications on laminitis. J. Dairy Sci. 80:1005-1028.

Oba, M., and M. S. Allen. 2003. Effects of diet fermentability on efficiency of microbial nitrogen production in lactating dairy cows. J. Dairy Sci. 86:195-207.

Pereira, M. N., E. F. Garrett, G. R. Oetzel, and L. E. Armentano. 1999. Partial replacement of forage with nonforage fiber sources in lactating cow diets. I. Performance and health. J. Dairy Sci. 82:2716-2730.

Raggio, G., D. Pacheco, R. Berthiaume, G. E. Lobley, D. Pellerin, G. Allard, P. Dubreuil, and H. Lapierre. 2004. Effect of level of metabolizable protein on splanchnic flux of amino acids in lactating dairy cows. J. Dairy Sci. 87:3461-3472.

SAS Institute. 1999. SAS/STAT User's Guide. Version 8. SAS Institute Inc., Cary, NC.

Schingoethe, D. J., M. J. Brouk, and C. P. Birkelo. 1999. Milk production and composition from cows fed wet corn distillers grains. J. Dairy Sci. 82:574-580.

Shingfield, K. J., and N. W. Offer. 1998. Evaluation of milk allantoin excretion as an index of microbial protein supply in lactating dairy cows. Anim. Sci. 67:371-385.

Tamminga, S. 1992. Nutrition management of dairy cows as a contribution to pollution control. J. Dairy Sci. 75:345-357.

Valadares, R. F. D., G. A. Broderick, S. C. Valadares Filho, and M. K. Clayton. 1999. Effect of Replacing Alfalfa Silage with High Moisture Corn on Ruminal Protein Synthesis Estimated from Excretion of Total Purine Derivatives. J. Dairy Sci. 82:2686-2696.

Van Soest, P. J. 1994. Nutritional Ecology of the Ruminant. 2nd ed. Cornell University Press, Ithaca, NY.

VandeHaar, M. J., and N. St-Pierre. 2006. Major advances in nutrition: Relevance to the sustainability of the dairy industry. J. Dairy Sci. 89:1280-1291.

Voelker Linton, J. A., and M. S. Allen. 2008. Nutrient demand interacts with forage family to affect intake and digestion responses in dairy cows. J. Dairy Sci. 91:2694-2701.

Whittet, K. M. 2004. Factors affecting variability in urinary creatinine and purine derivative excretion in beef cattle. MS Diss. Univ. Nebraska-Lincoln.

Wildman, E. E., G. M. Jones, P. E. Wagner, H. F. Troutt, and T. N. Lesch. 1982. A dairy cow body condition scoring system and its relationship to selected production characteristics. J. Dairy Sci. 65:495-501.

Zhan, X., D. Wang, M. R. Tuinstra, S. Bean, P. A. Seib, and X. S. Sun. 2003. Ethanol and lactic acid production as affected by sorghum genotype and location. Ind. Crops Prod. 18:245-255. 